\title{
An Expository Study of Witchcraft among the Basoga of Uganda
}

\author{
Isiko Alexander Paul* \\ Lecturer, Department of Religious Studies \& Philosophy, Faculty of Arts \& Social SciencesKyambogo \\ University, Uganda \\ *Corresponding Author:Isiko Alexander Paul, Lecturer, Department of Religious Studies \& Philosophy, \\ Faculty of Arts \& Social Sciences Kyambogo University, Uganda
}

\begin{abstract}
The concept of witchcraft has been defined by many scholars from the fields of anthropology, religion, sociology and cultural studies. Many times, there have been generalized arguments that witchcraft presents itself in the same way in all societies. Several authors have described witchcraft as a symbol of evil and that those who practise it have no place in society as they suffer constant witch hunt and possible death whenever discovered. To accept such generalized views that witchcraft was never tolerated in any African society points to a narrower conception of witchcraft as it also brings suspicion of 'othering' in society. Earlier writings beginning with colonial officials to Evans-Pritchard, Peter Geschierre, Peter Pels and others have conceptualized witchcraft as a 'deviant behavior' causing harm. They believe that this harm distorts societal order, and that witches are ever hunted down in those societies they happen to exist. Through interviews with traditional healers and lay members in Busoga, it is established that witchcraft is not entirely dreaded by this society since there are "tolerable acts of witchcraft". The glorification of witches and condemnation of witchcraft victims in Busoga society disproves previous theoretical conceptions of witchcraft in several African societies. This paper, therefore, addresses the specific ways in which Busoga society conceives witchcraft with specific interest in those aspects that make the Basoga glorify witches and condemn their victims. The paper argues that Busoga society's determination of 'acts of witchcraft' depends on the intention. Besides, some of these acts are legitimate with community approval. It is high time that we thought to re-examine witchcraft as not entirely deviant in itself but instead used as a legitimate weapon against deviant behavior.
\end{abstract}

Keywords: Witchcraft, Healing, Mystical forces, Religion, Busoga

\section{INTRODUCTION}

The concept of witchcraft is shrouded with mystery as it means different things to different people. There existed a defining point of difference between pre-colonial societies of Africa and medieval Europe with regard to witchcraft. The former attributed witchcraft to intra group conflicts and competition for leadership and resources, whereas the latter noted witchcraft to be the practice of magic aimed at manipulating nature for the benefit of the practitioner or his/her client (Mesaki 1995). In both cases, the overriding effect for witchcraft was to provide power and prestige to the practitioner (Meel 2009). Pre-colonial African societies had the experience of witches but knew how to live with them. Witches and witchcraft were part of their everyday reality (Wyk 2004). Criminalisation of witchcraft was a colonial invention in Africa, and therefore, was unheard of in pre-colonial African societies (Diwan 2004). The fear and ostracization of witches were introduced by European colonial rulers, as an extension of the witch hunt craze prevalent in medieval Europe (Bauer 2017; Meel 2009; Mesaki 1995; Mufuzi 2014). In his seminal work on witchcraft in Africa, Evans-Pritchard (1937) does not indicate the Azande witches of Sudan as experiencing witch hunt as it was in European societies. Azande witchcraft was different from European witchcraft (Kapferer 2002). This brings a presumption among scholars that the concept of witchcraft was a western invention, simply imposed unto Africa.

Therefore, the general understanding and description of witchcraft by western academia, colonial church and rulers is shaped in the context of power processes in Africa. It must also be understood as part of the larger discourse of 'othering' Africa (Ciekawy 1998; Kapferer 2002). They described and made witchcraft in Africa the way they wanted it to be, using western lenses of subjectivity. No effort was made to represent what constituted witchcraft from an African perspective. This eventually 
brought about distortions of African notions of witchcraft. Ciekawy (1998) has further analysed the misrepresentations that emerged with 'othering' of witchcraft in Africa. Several examples can be cited to locate these distortions. For example, the confluence of witchcraft and magic as it was assumed in medieval Europe was imported into Africa, focusing on negative aspects of magic and witchcraft, limiting the analysis of the positivity of witchcraft discourses in African societies; and association of witchcraft with crime and insecurity, leading to enactment of witchcraft ordinances in colonial states. In Uganda, where Busoga was one of the districts ruled by a British Governor, the Witchcraft ordinance of 1912 was passed, outlawing all forms of African traditional religious experiences, construing them as acts of witchcraft (Isiko 2018). This paper sets to purge such misrepresentations, intentional and unintended, in a bid to provide an African society ideology on witchcraft, from the perspective of an African society.

\section{Methodology}

This article is a follow up of an earlier study done for a $\mathrm{PhD}$ on Traditional Healing Practicesamong the Basoga'. Though the focus of the $\mathrm{PhD}$ research was not on witchcraft, it was established that some respondents held 'traditional healing' to be 'witchcraft'. Earlier writings about traditional healing by British colonial officials also seemed to suggest a confluence between healing and witchcraft practices. Using interviews and archival resources at the Uganda National Archives in Entebbe, the study sought to clarify the misconceptions held by various people about witchcraft in Busoga. Oneon-one interviews were conducted with traditional healers and lay people from Busoga sub region. Using the snowball sampling technique, interviewees were purposively selected. One interviewee would lead the researcher to the next person, thought to be in position to provide the kind of information that was desired. These included a total of twenty respondents. However, healersformed the largest number of the sample, making fifteen out of the twenty. It is difficult to state here that witches or sometimes qualified as witchdoctors were interviewed because, no persons in Busoga society, openly confess that they are witches. It is the rest of the society members that tag others as witches. Also,the misconception of healing as witchcraft is not a new phenomenon in African societies. This became a challenge when British colonial officials could not see any defining difference between the two. It was therefore necessary to visit the archives to establish the attitudes and ideologies of the British officials towards healing and witchcraft. Archival materials included colonial legal and policy documents on witchcraft, traditional healing and disease, colonial administrative directives to health workers and local population. Archival materials covered the period before 1960, because any records beyond this year would require seeking a rigorous permission from the office of the President, which was constrained by time to do so. But also colonial rule in Uganda, for which Busoga sub region is part ended in 1962.Use of archival data was important because several generations have passed since the end of colonial rule, and therefore getting people with first-hand information on colonial legacies on African witchcraft would be futile.

\section{SitUATING WITCHCRAFT PRACTICES IN BUSOGA}

Isiko (2019a) underscores the inextricable relationship that exist between traditional healing practices, including witchcraft and a society's socio-cultural, political, economic, religious beliefs and everyday life. He stresses that traditional healing practices of Busoga are a reflection of the location, population beliefs, socio-cultural, economic and political organisation of society. In their analysis of the sociocultural perspectives of the Bakonzo of Uganda about death, Isiko and Maate (2019), argue that all social and cultural phenomena are constructed and informed by religion, language and culture. It is argued here too, that witchcraft practices are part of each society's cultural phenomena. It is therefore important that we understand how witchcraft practices emerge from such society setting.Busoga is one of the significant ethnic Bantu groups found in Uganda. Busoga is a sub region in the eastern part of the country. Several scholars have written about the unique geographical location of Busoga. Scholars like Fallers (1965), Nayenga (1972), Cohen (1972) and recently Isiko (2019a; 2018) describe Busoga as an Island, being separated from her neighbours by major lakes and rivers on all boundaries. Busoga sub region is made by lake Kyoga in the north, separating it from Lango and Teso sub regions. Busoga is also separated from Buganda in the west by Victoria Nile. In the east, Busoga is separated from Bukedi region by river Mpologoma, whereas in the south, Busoga is separated from other Bantu groups and the United Republic of Tanzania by Lake Victoria. On either sides of the boundary, there exist unique societies, who are neighbours to Busoga. Isiko (2019a) has argued how Busoga's proximity with her neighbours has led to infiltration by people from neighbouring societies 
for trade, employment and leisure. Some of these have permanently settled among the Basoga aided by a high degree of intermarriages. The migrants continue with their traditions, including those connected with witchcraft. This has led to fluidity in the Kisoga witchcraft practices, resulting in a hybrid of witchcraft practices, especially in the urban centres.

The language spoken by the Basoga is Lusoga, a Bantu language in the Niger-Congo family. As in the Bantu languages in the Lake Victoria region, nouns among the Basoga are reflected by changing prefixes: human beings are indicated by the prefix $B a$ (plural) and $M u$ (singular); the name of the country (region) by the prefix $B u$; the language by the prefix $L u$ and an adjective derived from any of these by the prefix Ki. Thus, the region is called Busoga; the people are Basoga (singular, Musoga); the language is Lusoga; and "of the Basoga" is described as Kisoga.Referring to the National Collaborating Center for Aboriginal Health in Canada, Isiko underscores the importance of language in influencing people's perceptions and ideologies towards their cultural heritage, of which witchcraft practices are applicable in the case of Busoga (Isiko 2019a; Isiko2018). Therefore, understanding Lusoga language terminologies of witchcraft will help in getting intrinsic meanings that the Basoga attach to witchcraft practices.

The socio-cultural setting of Busoga is hierarchical with a clan system as the fulcrum of societal organisation. Each clan has its witchdoctor, who sometimes is called healer. Some clans are labelled to hold superior witchcraft powers than others. The traditional religious beliefs of the Basoga are still rife, but largely concerned with protection of life against evil forces of witchcraft. Whereas Busoga has witnessed infiltration of foreign religions like Christianity and Islam, and it is fashionable to belong to either of the two, where and when perceived forces of evil strike in a family, the Basoga return to consult their traditional religious gods. The current wave of the 'born again church movement' in Busoga is not just a reformation of the mainstream Christian churches (Isiko 2019b), but has also waged war on witchcraft practices, using open condemnation to burning down shrines of perceived witches. This has pitied the new Christian movement against Kisoga traditional religious beliefs much ingrained in witchcraft ideologies. The preoccupation of the born again church pastors with casting out of demons, along with the attendant methodologies they employ to do so, makes it difficult to tell the difference between them and the witchdoctors (Leistner 2014). There is therefore, noticeable reasonable competition between witchdoctors and born again church pastors in Busoga, over superiority upon evil forces.

The political organisation of pre-colonial Busoga society was in such a way that chiefs and spiritualists had a united political voice in their societies. Political chiefs were the chief custodians of traditional knowledge, yet their political positions were guaranteed by spiritualists (Isiko 2019a). For example, traditional religious leaders like diviners and priests were such a powerful force to reckon with, that kings and chiefs would not assume their offices without their approval (Isiko 2019b). Even in the current political dispensation, such religious leaders, both traditional and of foreign religions hold opinionated political views that sway the electorate in the direction they may wish. Therefore, many ambitious individuals aspiring to the status and wealth associated with political power, utilise witchcraft. African politics cannot be understood if the role of the occult is ignored(Leistner 2014).

Busoga society depends largely on agriculture to sustain her people. Busoga is however, one of the much impoverished regions in the country. The argument by Leistner (2014) that witchcraft is strongest in poor communities and becomes weaker as prosperity rises and is more widely dispersed, could be true for Busoga. Agriculture makes land the most important property because it is not just a basis of one's economic survival but also defines ones' ancestry (Isiko 2019a). Land is one of the most protected resources yet a source of contestations among the Basoga. Attempts to safeguard one's land, make witchcraft one of the important options to undertake to secure land and one's survival.The manifestation of witchcraft in the economic organisation of society certainly affects development of society negatively. Leistner (2014) has grossly articulated how witchcraft negatively impacts a society's economic development. He argues that amongst people whose economic basis is so narrow that they barely survive, as is so often the case in Africa, jealousy and suspicion of witchcraft are readily created by even minute changes in a neighbour's level of living. Given traditional society's belief in limited supply of goods, including life-force and good fortune, it logically interprets the unequal distribution of wealth and success among people and nations as the result of witchcraft. Anyone not conforming to the egalitarian norm by harvesting more or otherwise being more successful than the rest of the community, is suspected of having benefitted by utilising magic to steal 
life-force from other people. Witches are widely believed to owe their wealth to the employment of 'zombies' who work for them at night or on far-away fields.After analysing Busoga societal set up and the attached central importance of witchcraft, it therefore necessary, that we get to understand the way the people of Busoga conceive witchcraft.

To the Basoga, 'witchcraft' is the use of mystical powers for wicked purposes and is usually applied or practised in secrecy. The motives of witchcraft are to cause harm, pain and kill the victim. The Lusoga word for witchcraft is bulogo. Witchcraft takes mainly two forms. These are basezi (Night dancers) and balogo (Sorcerers). Although in everyday talk the two are used interchangeably, technically there is a difference. A person who practises witchcraft is called a 'mulogo' or 'witch' (singular), and 'balogo' (plural). Therefore, all categories of witches are loosely called 'Balogo', the right word for sorcerers. There is, however, a difference between basezi and balogo in Busoga as we shall see later. Whereas both men and women can be witches, women are more likely to be categorised as such (Isiko 2018). The basezi are driven by the spirit of evil (ekitambo) to harm those around them. They practise their trade especially at home, in the compounds, and gardens of those they intend to harm or kill. Basezi are said to be the major cause of sickness and ill-being in communities. They behave rather oddly in the society. For example, they walk naked at night when undertaking their evil activities, dance wildly, and scare those who move at night. They are said to walk with their heads on the ground and the legs up in the air, and are earnestly annoyed with those who identify them in the dark as basezi (Isiko 2018). This may lead to the death of those who identify them. They are known to dig up corpses that have just been buried to eat them, and they use certain parts of dead bodies to mix with their medicine that they use to cause sickness upon those they hate ( $\mathrm{S}$. Kawuma, personal interview, May 05, 2017).

The balogo, on the other hand, are not driven by any mystical powers. These are just ill-intentioned individuals in society who do not wish to see others progress. This is because bulogo is driven by hatred for someone, quarrelling and/or jealousy. The Basoga believe that Bulogo is practised against those whom they hate. These may include people like adulterers, co-wives, thieves, step children and those who insult others rudely without sound reason. If one has a disagreement with another and he dies suddenly, or some an unfortunate experience takes place in his family, the other would automatically be called mulogo-being held responsible for such a misfortune. Unlike the basezi, who invoke mystical powers, the Balogo use poisonous medicine to make others sick by putting it in food, water, clothes, bed, in the kitchen and suchlike. It is common among co-wives to make others sick by concealing their harmful medicine in the gardens where their victims will go to dig and collect food. These kinds of activities can only be done by someone who knows the other very well. This is the very reason why upon the death of someone in Busoga or upon sudden illness experienced by someone, the most immediate person held responsible is the neighbour or close relative. This is the reason for the Kisoga saying, 'anakwita tava wala', meaning that he/she who will kill you does not come from far away (E. Namwase, personal interview, October 11, 2018).

The Basoga contend that balogo can send their harmful medicine through objects that may be living or non-living. For example, a pigeon (engyibwa) is a well-known bird used by sorcerers in Busoga to take poisonous medicine to the homes of perceived enemies. And because of this, pigeons are rarely kept by Basoga. Snakes can also be used. This is the reason why a snake bite cannot be taken as an accident. Bulogo is attributed to be the cause of accidents among the Basoga. This is supposedly the reason why some people involved in the same motor accident may die yet others survive without any scratch. The sorcerers are also said to manipulate traditional medicinal power so that somebody is attacked by a wild animal. In an interview with P. Kalogo (personal interview, October 15, 2018) it was established that Bulogo or poisonous medicine can be employed by a sorcerer to kill one's cowives and their children. There are instances told of how a co-wife concealed poisonous medicine targeting her co-wife and instead she or her own children became the victims and died.

Several other forms of witchcraft were identified by interviewees. These include 'rain stoppers' (abachinga amadhi). Rain stoppers are believed to possess powers that can withhold rain for a long time. These are the first suspects when an area experiences a long dry spell. Ironically, there are circumstances when rain stoppers may be called upon to stop rain. This is usually in times of funeral or communal festivals, where a community does not want interruption. Other witches include those who send hailstones, lightening and suchlike. The significance of rain stoppers is one such example to demonstrate that there exist circumstances when witches are useful and therefore tolerated in society. 
To many outsiders of Busoga society, they cannot tell the difference between witches and healers. All are classified as witches for they all use supernatural powers to carry out their activities. To the Basoga, there is a difference between witches and healers.

The above conceptions of witchcraft by the people of Busoga have ramifications on society. These are both positive and negative. Positive in the sense that to the Basoga, witchcraft is an institution, which is used to check on excesses of some people. For example, due to the kind of power and influence that spiritualists hold in society, politicians consult them, and their advice may promote good governance. Negatively, witchcraft beliefs lead to stunted economic development due to belief in witchcraft to cause wealth and people end up not working hard or failure to accumulate wealth, for fear of being suspected to have been gotten out of witchcraft. Witchcraft beliefs are likely to erode trust and cooperation due to fears of witchcraft attacks and accusations. Studies undertaken byGershman (2016) in sub Saharan Africa demonstrate how the 'evil eye' syndrome leads to underinvestment and other forms of unproductive behavior due to the fear of destructive envy, where envy is likely to manifest in destruction and vandalism involving those who own wealth. Society ends up being governed by those who are not deserving because the decisions on governance made are not based on rationality or public will but a few spiritualists, whose will cannot be questioned. However, in order to clearly understand the extent of glorification of witches, we need not to confuse them with healers, who are not an aspect of contestation among the Basoga, yet often and wrongly described as witches.

\section{Correlation between WitchCraft AND Healing}

To some people in Busoga, there is suspicion towards healers as the source of sickness. The belief that there could be a connection between the activities of the healer and the witch is strong among the people (K. Balimwikungu, personal interview, October 20,2018). Due to monetization of the business of healing, healers can send spiritual forces or plant witchcraft in one's home so that he/she could go to the healer's place for healing in exchange for money. K. Balimwikungu, convincingly articulates that witchcraft is a reality in Busoga society as there are several persons who are believed to die of unclear causes not easily explained by medical doctors(personal interview, October 20, 2018).

To the ordinary mind the supposed difference between 'mulogo' (witch) and musagho (healer) is spurious. Interviews held with healers provided important insights that can be used to explain the difference between a witch and a healer. Healers just like witches use 'medicine' (obulezi) to cure sicknesses and cause ill-being respectively among people. Obulezi meaning 'herbs' used by both could be in the form of a 'tree' or 'root', translated as 'omuti' and 'omuzzi' respectively. Even when the healer or witch may have used other medicinal substances to promote wellbeing or suffering, the Basoga will refer to such medicine as 'omuti or omuzzi, especially if they do not use the general word of 'obulezi. Statements used in reference to application of obulezi can refer to either witchcraft or healing. For example, when the Basoga say, 'yamusimbira obulezi', literally meaning 'one applied medicine onto him or her', this could mean on one hand that the medicine applied was for promotion of the other person's health, or his/her protection. On the other hand, the medicine could have been for destruction of the person upon whom it was applied. Therefore, the difference between 'healing' and 'witchcraft' is determined by the 'intention' and 'effect' of the medicine upon the person.

Relatedly, the Kisoga statement 'yamuwa obulezi', literally meaning 'he/she was given medicine', takes both the positive attitude of healing medicine and negative description of witchcraft. In this very context, the literal meaning of 'giving medicine' where the intention is known to the recipient is 'healing'. In the context of witchcraft, the 'giving (yamuwa) of medicine' is not known to the victim. Conceptually, among the Basoga, witchcraft is usually performed in secrecy, quite oblivious of the victim.Consequently, whereas there exists a thin line between healing and witchcraft among the Basoga, there are two general indicators of difference. These indicators are: intention of the medicine and the effect that the medicine brings upon the patient's or society's wellbeing. If the intention is to cause harm, unhappiness and ill-being, resulting into sickness and or death, then the use of obulezi is witchcraft.

On the contrary, if the intention of the medicine is to restore wellbeing and do away with ill being, then the use of obulezi is clearly healing. Busoga healers take on the identity of witches in circumstances when the patient dies in the midst of healing. This is because death is associated with witches and not healers. Therefore, as Ashforth (2005) puts it, a distinction between healing and witchcraft is essentially a moral one, based on interpretations of the motives of persons using the 
obulezi and the effects that the supernatural medicine brings through application of the obulezi. The use of mystical powers to do good has often been erroneously constructed to be witchcraft. The idea that there is a positive view of witchcraft powers as held by Bauer (2017) is inconsistent with Busoga perspectives. Among the Basoga, witchcraft is held to be inherently evil and even when there is community approval for its application, members are aware that it is going to have disastrous effects upon those it is to be applied. The perspectives of the Basoga about witchcraft, therefore, points to the subjective nature by which actions of witchcraft are determined. These perspectives vary from one society to another.

\section{MisconCEPTIONS ABOUT WitChCRAFT In AFRiCA}

The concept of witchcraft is understood differently by the different societies in Africa (Diwan 2004). This poses different ideas and problems associated with it. Some of these are generalizations while others are specific in nature. Such generalizations have been influenced by Christianity, Islam and the general colonial epistemologies about Africa. This is what Mesaki (1995) calls ethnocentric prejudices that prevents an objective approach to understandingwitchcraft in African societies. During the witch hunt craze in Europe, witches were identified to be women, and witchcraft was defined in relation to female sex. Mufuzi (2014), refers to the Cambridge International Dictionary of English of 1996, defining witches as women believed to have magical powers and uses them to harm other people. Narratives of witchcraft in European societies, were mostly about evil women and such women experienced massive killings (Wyk 2004). Such analyses exclude men as potential witches. In Uganda for example, the only case reported under the witchcraft ordinance of 1912, was in 1931, involving two men who were tried in the High Court of Mbale (Uganda Protectorate 1957). This evidence affirms the erroneous categorization of witchcraft in Africa. To this end, witches in Busoga can be both males and females. It is on this basis that I argue that there have been strong misconceptions of witchcraft, which were started by colonial officials in Africa, often denying its reality (Isiko, 2018; Mufuzi, 2014).

Isiko (2018) further analyses arguments by Peter Pels, Geschiere and Evans Pritchard to unravel these misconceptions. Peter Pels, in his recollection of western thought about witchcraft, states how colonial European rulers ruled out the reality of witchcraft in Africa, but moved on to enact witchcraft ordinances to regulate it (Pels 1998). In his analysis of Evans-Pritchard's work, Pels recognises the western considerations of the unreality of witchcraft, describing it as simply an imaginary offence that cannot be proven (Pels 1998). Peter Geschiere also discusses how the French, British and Belgians challenged the reality of witchcraft, accusing healers of defamation and disturbance of the peace (Geschiere 2010). Russell and Lewis (2016) are suggestive of 'witchcraft' being a mere imagination and a stereotype held by contemporaries. The belief in witchcraft was therefore categorized as irrational and unreliable and that its practitioners were mere charlatans and mentally sick (Mufuzi 2014). However, the belief in reality of witchcraft among African societies cannot be over emphasised. African peoples of all backgrounds, regardless of academic status, rural-urban divide, gender, socio-economic status, politicians and scientists as well as Christian pastors are convinced that witchcraft is a real threat to African societies (Kohnert 1996).

The British colonialists' omnibus reference to all Kisoga healing practices as witchcraft may have been influenced by their failure to see any defining difference between healing and witchcraft (Isiko 2018). Isiko (2018) and World Bank (2004) affirm that in pre-colonial Uganda, traditional medicine was the only healthcare system. Under colonial control, traditional medicine practice was equated to witchcraft and seen as contrary to the ideals of the pre-eminent colonial religion and western medicine. Until now, in Uganda, traditional medicine was legislated under the still-functioning Witchcraft Act of 1957. All traditional healers were classed as witches, and they were erroneously labelled 'Witchdoctors'. Witches cannot be 'doctors' because they do not deal with 'medicines' in their evil work (Mesaki 1995; Wyk 2004). However, stringent punishments were spelt out for those guilty of practising witchcraft (Isiko 2018). Fields Karen illustrates how Ugandan administrators charged ordinary persons under the witchcraft ordinance, when found in possession of charms, even when intended for personal means. Such apprehended suspects had responsibility to prove that they were not intended for destruction of others (Fields 1982). The colonial law in Uganda prohibited possession of any articles used in healing. Section 6 of the 1957 Witchcraft Act provided for the confiscation and destruction of herbs and any other resources used in traditional healing (Uganda 
Protectorate Government 1957).This clearly demonstrates the lack of understanding on the part of the British colonial officials, who construed the cherished indigenous knowledge of healing as witchcraft.

Unfortunately, anthropologists writing about Africa, like Peter Pels (2014), falsely believed this kind of misjudgment by European colonial officials. They acknowledge that renaming African healing with African science was one way of enhancing the rationality of 'witchcraft'. This made the practice of witchcraft an offence per se, regardless of the purpose for which the act may be committed. Isiko (2018) has discussed how, by 1946, Europeans were still grappling with the untamed confidence that locals had in their traditional healers whom the latter insisted oncalling witchdoctors (Cook 1946). The fact that African forms of witchcraft did not resonate with western forms of civilization, was basis for its misconception. And Europeans, now took it upon themselves to define and redefine what was essentially African in nature, using western models of a 'civilized' society.

It is also common to categorise all mystical non-western scientific practices and supernatural influenced activities in Africa as witchcraft, whether done for the good or bad of society. This transforms into the erroneous categorisation of witchcraft into bad or good (Bauer 2017). The following tenets help to distinguish witchcraft from other supernatural mystical practices that are not. The first and the most important is that witchcraft involves the use of supernatural forces for evil or harmful intentions, other than for benevolent purposes (Kapferer 2002; Diwan 2004). Witches manipulate supernatural forces to cause harm on human beings and their surroundings. Witchcraft, therefore, involves the anti-social employment of mystical powers to harm others and their possessions (Wyk 2004). In Busoga and so are several other societies in Africa, there exists no dichotomy in witchcraft; with one being good and another bad. The perception of the Basoga is that witchcraft is all bad though can, in some instances as we shall see later, have community approval. Communal acceptance of witchcraft does not in any way make it good, just as a death sentence by a court of law may be legal but not legitimate. Witchcraft is therefore a term used to describe evil that some people inflict on others (Wyk 2004). The irony however, is that this evil is tolerable in some societies. This is in contradiction with the western world thinking which categorises witchcraft, sometimes confused with magic, as being both malevolent and benevolent. Such misconceptions have been a result of using a single study of witchcraft in one particular society to generalise to the whole of Africa. So, conceptually, witchcraft differs from one African society to another. That is why scholars such as Mesaki (1995) have argued that Evans-Pritchard never generalised his discoveries to all African societies but confined them to the Azande people.

Contrary to Russell and Lewis (2016) assertions about witches in the European societies, African witches never sought to gain or preserve health, to acquire or retain property, to protect against natural disasters or evil spirits, and to help friends. Also, Bauer (2017) thinks that there is a good side to witchcraft involving the availability of power to enhance one's ability to perform extraordinary things, leading to personal improvements, social advancement, gaining wealth, protection from sickness and danger and foretelling. But these descriptions do not in any way constitute any single element of witchcraft but divination and healing; two of the practices that are safeguards against witchcraft practices. Witchcraft ought to be inherently negative, no matter whether it could be accommodated by some communities. Witchcraft in Busoga is intended to destroy the harmony that exists in society. However, such misconceptions are magnified by the media to produce a distorted image of witchcraft, making it difficult to fight the practice. For example, in one of the editorials of Daily Monitor, a Ugandan Newspaper, it was stated that witchcraft thrived through the protective power of sacrifices to spirits and ancestors (Monitor editorial, Tuesday $12^{\text {th }}$ January 2016). But protective charms and power are used by those in fear of witchcraft and are not witchcraft practices in themselves because these have no aim of causing injury to any other party other than protecting the person that uses or wears it. Voices of Christian pastors and evangelists are common discouraging followers from wearing 'witchcraft' articles like 'yilizi', which points to a true reflection of the generalisations of African mystical practices as witchcraft. Those carrying such "witchcraft articles" in Busoga are never ostracised. However, the same newspaper article purges perceptions that witchcraft practices are only among the poor, uneducated and non-literate segments of society. It highlights the prevalence of witchcraft among highly schooled Ugandans manning Ugandan Embassies abroad using witchcraft to thwart workmates envious of their positions.

The second important characteristic of witchcraft is that witches operate in secrecy, their victims oblivious of it (Hutton 2004; Isiko 2018). On the contrary, diviners, traditional bone setters, herbalists 
of all nature, traditional birth attendants and medicine men and women sellingtraditional herbs in the public markets have been classified as witches. For example, Bauer (2017) and Mufuzi (2014) argue that there is a confluence between a diviner and a witch. They highlight divination as one of the four main categories of witchcraft, used to detect causes of death and misfortune. However, to the Basoga, divination and witchcraft are in opposition to each other. Whereas witchcraft is destructive, divination brings restoration. In the real essence of witchcraft, with a sole target of causing harm and pain, detection and counteracting misfortunes cannot by this description be witchcraft. Indeed, African Traditional Religion and African healing practices, to which divination is part, have as one of their most important functions the struggle against witchcraft (Wyk 2004).

Many other activities like use of 'love potion' have been misconceived as witchcraft when they induce love other than hatred. For instance, traditional healers, usually female healers, whose specialization is dealing with marriage challenges are erroneously classified as witchdoctors. Yet, these have taken centre stage using traditional herbs as marriage counsellors and sex education volunteers thus replacing the old and waning institution of aunts (Senga) and uncles (Kojja) who were the ultimate consultants on these issues, especially for young men and women. Having strategically placed themselves as marital counsellors, traditional healers claim to be experts on how to stabilize marriages (okutereza Amaka) and on sex education. No wonder many of the healers who offer these services take on the title of 'Sengaand Koija' for men and women respectively (S. Kawuma, personal interview, May 05, 2017).The efficacy of traditional healers' role in the marriage institution has less to do with the herbs and spiritual powers that they espouse to have, than with their ability to offer psycho-social support to those experiencing marital challenges. They have mastered the art of marriage relationships, and some of them being elderly and having been married for quite a long time, understand the challenges involved. Traditional healers teach women among others to be submissive to their husbands, look physically attractive and ensure that they maintain clean homesteads (Isiko 2018).

Monotheistic religions of Christianity, Judaism and Islam construe African traditional religions as witchcraft. Christian missionaries interpreted Africans' preference of ancestral spirits to the Christian God as witchcraft (Mesaki 1995). Christian writers like Magoola (2013) have argued that the strength of African traditional religions in Busoga is entrenched in witchcraft practices. And that witcheraft is deeply rooted in African theodicy (Wyk 2004). Bauer (2017), also states that cultural assumptions of witchcraft are rooted in African traditional religions. Other writers contend that witchcraft is part and parcel of the moral structure of African religion (Gechiko-Nyabwari and Nkonge-Kagema2014). Christian pastors and Moslem clerics alike attempt to make their new African converts to believe that reverence of traditional gods is witchcraft.

However, one of the major roles of African traditional religious leaders was to protect people against acts of witchcraft. The practice of witchcraft in African societies is a secret affair as opposed to public practice of African religions (Russell and Lewis 2016). Christian churches discourage those who cleanse their new business premises by sprinkling herbs around them, with the claim that it is an act witchcraft. Some people consult a healer before they begin to dig a foundation for a new house. There are also traditional medicines for attracting clients to ones' business, called, 'akasenda abaguzi' (P. Mandwa, personal interview, October 10,2018). Protection of one's economic resources especially property is cherished among the Basoga. This is called 'okuchinga' (Isiko 2018). None of these activities above aim to cause injury or destruction to any other person apart from luring clients to one's business and providing protection to property. The idea that some people are not always happy with another's success breeds suspicion of witchcraft among neighbours, hence the saying; 'ezira ayenda eyamwine ezale eibiri' (P. Mandwa, personal interview, October 10, 2018). This literally means that no one wishes to see another person's cow or goat produce twin calves or kids. This necessitates seeking the services of medicine men and women to provide 'protective medicine' to one's wealth.

Kingsley Mary (1901), writing much earlier than Evans Pritchard (1937), contested the anthropological assertions that promoted and continue to do so, the indistinguishable fusion ofwitchcraft and African traditional religions. She argues that witchcraft and African traditional religions stand widely apart and are always irreconcilably hostile to each other. Witchcraft is built upon rudimentary science as it does not rely on prayer, worship or propitiation of divinities, but upon a secret knowledge and experience of the effect producible by certain tricks and mysterious devices 
upon unseen powers. Unlike religion and its priests that serve the supernatural powers, witchcraft and its agents tap in the unseen supernatural powers to fulfill their personal and selfish harmful activities. It is on this basis that whereas religion and witchcraft are related to the application of unseen supernatural powers, the former is a virtue while the latter is a vice, always denounced and detested by religion (Kingsley 1901). In the case of Busoga society, African traditional religious agents like the priests (Mandwa) and priestesses (Lukowe) serve the supreme god (Lubaale) of the Basoga, and their powers come from him. The role of the Mandwa and Lukowe is to lead people to the experience of Lubaale, through prayers and offering of sacrifices. These further mediate between Lubaale and the people, making the will of the Lubaale known to the people. The priests and priestesses accomplish the will of Lubaale but not their own will. On the other hand, the witches do not serve Lubaale but instead tap into the supernatural powers of malevolent beings to do harm $(\mathrm{H}$. Namuwaya, personal interview, October 28, 2018).

Therefore, this points to the subjective nature by which people categorise witchcraft practices. To the Christians, all what African traditionalists do which is not provided for in the bible is witchcraft. To the British colonial officials, anything that was done by the Basoga to promote or destroy life as long as it did not conform to western scientific mode of medicine was witchcraft. In the next section, analysis of those mystical practices that aim to destroy, kill and harm are presented but not as condemned but glorified. Additionally, these are performed with full knowledge of society that points to their heroic status, contrary to the believed treatment of witches in other societies. This contradiction from what has always been presented by authors that witches are ostracised wherever they existed is unique in Busoga society.

\section{GLORIFICATION OF WitCHES IN SOCIETY}

Several authors including Gechiko-Nyabwari and Nkonge-Kagema (2014) have described witchcraft as a symbol of evil and that those who practice it have no place in society as they suffer constant witch hunt and possible death whenever discovered. To accept the generalized view by GechikoNyabwari and Nkonge-Kagema (2014) that witchcraft was never tolerated in any African society points to a narrower conception of witchcraft. Studying the Transkei community in South Africa, Meel (2009) established witchcraft and witches as not always considered as bad in some parts of the world. In the editorial of Daily Monitor Newspaper, the glorification of witchcraft was highlighted among diplomats running Uganda's embassies in foreign capitals (Monitor editorial, Tuesday $12^{\text {th }}$ January 2016). This is affirmation of how witchcraft beliefs and practices have increased at the same rate with modernization and many Africans increasingly believe in its effectiveness in solving challenges (Kohnert 1996). The unregulated advertising of witchcraft services in the newspapers and major radio stations points to societal approval of the vice. This demonstrates how witchcraft practices have firmly taken root, permeating the entire society including the elites. This is not unique to Busoga or Uganda, Meel (2009) has discovered witchcraft to be rife among the literate and educated sections of South African societies. If witchcraft's intention is to cause pain, harm and death to the victims, then, there are exceptions to this ideology among the Basoga of Uganda, where community sides with the witch against his/her victims. My argument is that just as capital punishment is legal in several modern countries, yet it deliberately takes away human life, so are some acts of witchcraft in Busoga. There exists community approval of witchcraft practices upon those thought to be social deviants, disrespecting cultural norms and traditions. I have also established that contrary to generalized beliefs that witches act in hiding and seem to be an individual act, there exist communal acts of witchcraft especially against other communities.

The use of witchcraft to protect life and property against unauthorized agents like thieves and murderers (locally called 'okuchinga') is common among the Basoga. Theft or attempt to steal such 'medicine protected property' may result in untold suffering of the thief including death. The community celebrates along with the person who (in the essential meaning of 'witch', as one who uses medicine to cause harm or destruction) would have used protective medicine to cause death of a thief. Society further tolerates a desperate husband who uses traditional medicine to make his adulterous wife 'get stuck', having sex (okulemeramu) with her lover (L. Mpadwa, personal interview, October 23, 2018). This specific condition of 'getting stuck' during sexual intercourse is associated with several myths and beliefs among local Basoga. Modern science calls this condition 'penis captivus', a condition when the penis in the vagina becomes increasingly engorged while the muscles of the woman's pelvic floor contract at orgasm, making the penis to become stuck. Literary, 
the genitals of those having sex become inseparable, leading to pain and anxiety (Taylor 1979; Kantha 2014). Basoga people believe that this condition can happen when desperate husbands and wives wishing to arrest their partners red handed in actions of adultery use traditional medicine to make their cheating partners get stuck with their lovers during sex. Locals, especially the uneducated believe in the efficacy of traditional medicine to make this condition happen. Ironically, the pain that the adulterous couple experience because of 'getting stuck' during sex is not attributed to the 'evil power' of the medicine used but rather the 'effective power' of the protective medicine used by the desperate husband.

Interviewees also identified the 'sending back' of obulezi (medicine) to the witch, but this time technically called 'eirogo'. (H. Samanya and B. Wairagala, personal interviews, October 26, 2018).Eirogo is the correct word for 'medicine' when used for witchcraft intentions. All these indicate that a person can take on a dual identity of healer and witch. It is therefore clear that the Basoga tolerate those acts of witchcraft which serve as deterrence to what society considers 'deviant behaviour'. These exceptions in witchcraft beliefs among the Basoga augments Peter Pels theory that rather than looking at witchcraft as only destructive, it should as well be a social system that is used to regulate society (Pels 2003). These societal contradictions qualify witchcraft and healing as embodiments of true 'African science' as they serve as basic references for reckonings of the potentials of secret African knowledge and skills (Ashforth 2005). The contradicting beliefs in witchcraft cast doubt as to whether these practices are indeed witchcraft, or they seem to be as Africans try to cope with the European's definition of witches. The glorification of witchcraft among the Basoga for the reasons described above checks against earlier writings by Cohan (2011) and Hutton (2004) who argued that witchcraft always receives social disapproval, since it is against natural order of harmonious community life. Further, community legitimacy of some acts of witchcraft is indeed a legitimate retribution for bad character in society. Instead of condemnation of the witch for killing a thief or an adulterous man, society will praise the spiritual prowess of the witch. This may endear so many people to the witch with similar requests.

Land is one of the most important resources in Busoga society and is a much protected one. Attempt to dislodge one from his/her land may warrant consulting a witch to deal with the land grabber. The poor prefer using witches to deal with land grabbers than consulting courts of law, which are seen to be corrupt, partial and where cases take long to be decided. When the poor become successful and the land grabber is killed by the powerful forces of the witch, he becomes a celebrity in his/her society as other society members would seek his services to deal with similar peoples disturbing them on their land. The witch becomes a consultant on how to deal with such land grabbers. Isiko (2018) has analysed land as a basis of feuds between societies and individuals. A disagreement over land, usually, leads the aggrieved to undertake witchcraft to punish the other. Several deaths are attributed to witchcraft in connection to land disputes. Namwase Edisa explained that a land dispute is never won on merit; even if one of the claimants dies a natural death, it is attributed to the powerful forces of the witch the enemy may have visited. Land grabbing in a customary land tenure system in Busoga, is interpreted as disobedience to society's traditional customary laws relating to land redistribution. Witchcraftupon such kinds of land grabbers is interpreted to be a just punishment for disobedience against community rules (Kohnert 1996). Mutesi Kawanguzi (personal interview, October 21, 2018), an Aunt to two brothers, one poor and another rich, feuding over a piece of land, commented saying that the poor brother better gives up on the fight because the rich one had the capacity not only to bribe the courts of law but also hire witches who can help him do away with his poor rival. This points to toleration of witchcraft to solve land conflicts is an indication that people hold strong beliefs in them. But it also highlights witchcraft as being used to regulate communal modes of production in a society with strong beliefs in witchcraft (Kohnert 1996). M. Kibalya (personal interview, October 7 , 2018) articulated how witches are hired to torment thieves and those who would have committed mischief in society. Under these circumstances, a number of hardships are encountered by the thief. For example, with the powerful forces of the witch, the thief may experience hardship with talking and becoming deaf completely. He may become mad or blind until the property stolen is returned. He may be compelled to walk long distances on foot to return the property, or he may be attacked by bees that bite him to unconsciousness. In these circumstances, the causer of the pain upon the victim is well known contrary to earlier conceptions by earlier writers that witches practise their trade in hiding and remain anonymous to their victims. They become both feared and revered, and are given titles that demonstrate their abilities in witchcraft. The titles accorded to them clearly demonstrate their power 
in society. People therefore come to accept them as agents of societal regulation as they attract people from within and outside their localities.

Cursing a disrespectful child by an aunt or uncle though not promoted is neither condemned. Technically, cursing is a form of witchcraft though not accepted by many Basoga. Cursing as witchcraft is based on the notion that its end result is to deprive the cursed person peace and harmony, subsequently leading to his or her slow death. Actions of those who curse are not any different from mainstream witches; their intention is to cause pain to their victims. For example, they may decree that the affected person will never marry, stay in poverty forever, remain homeless, receive no favors from anyone, stay childless and jobless however educated he/she may be etc. Non-acceptance of cursing as witchcraft is based on the rationale for cursing as deterrence to offending elders. The Basoga justify cursing as the 'cursed' is blamed for having brought it upon himself/herself for failure to respect elders or perform roles that were expected of him/her. Those who curse are therefore not ostracized by community but instead pleaded with to undo the curses. Unlike witches, who may be tormented and killed, those known to have cursed anybody need to be appeased to reverse the situation. This attitude is premised on society thinking that people do not curse without a valid reason. Something very serious must have happened and the culprit must have failed to make amends (Cultural Research Center 2003). The Basoga have well elaborate ceremonies and rituals intended to reverse the curses, whereupon the one who has cursed makes demands and they have to be honored to reverse the situation. The whole clan may be required to assemble to plead with the uncle or aunt to forgive the son or daughter who was cursed.

The practice of witchcraft in political contestations has become common place in not only Busoga society but Uganda at large. Several interviewees argued how groups of people supporting one candidate can pull resources together, with or without the approval of the candidate for purposes of consulting a witch, capable of killing the opposition candidate through use of eirogo. Witchcraft is used as a defensive weapon in political contestations for supremacy between rival politicians (Kohnert 1996). Instances of political candidates getting involved in motor accidents and dying during campaigns at all levels of political participation are largely attributed to the evil powers of witchcraft. The result is always counter accusations of witchcraft from rival candidates. These then become communal activities of witchcraft, seen to be legitimate by members of that community against another. Winning such political contestations is attributed to the powerful roles of the witch, which in this sense are judged positively by both rival parties. The losing political group become jittery not because the rivals used witchcraft to win political office, but because their witch was not able to outcompete the other to give themvictory. One interviewee narrated a story of a prominent witch at Bulagala village in Namutumba District, who died from natural causes but would not be buried until a certain Member of Parliament from a faraway constituency arrived. It was told that the late was her chief witch who helped her win a parliamentary seat against her rival. It is usual for community members to approach a village witch to cause death of a dictatorial leader in their community. Kohnert has written about the way dictatorial rulers of Africa like the late Mobutu of Zaire, currently Democratic Republic of Congo was using witchcraft to fight and dominate political opposition groups and exploit his citizens during his long tenure of the presidency.Because political contestations are struggles for power and resources in a society which is already impoverished, witchcraft beliefs and practices become desperate measures people to resort in the hope of gaining victory. All these illustrate the centrality and instrumentalisation of witchcraft beliefs in political activities (Kohnert 1996). Successful rebel activities in the early 1980s of now President Yoweri Museveni were attributed to the use of witchcraft which enabled the National Resistance Army (NRA) to achieve victory over the reigning government of the time. Using witchcraft, the then rebel leader, Museveni Yoweri, became elusive to the then governments of Dr. Milton Obote and Mr. Okello Lutwa in power. It is told that the witchcraft would enable Mr. Museveni Yoweri to turn into familiars when surrounded by government military forces. He could change into a cat or a rat. There has been no condemnation of such stories as having been evil because the use of witchcraft enabled the Ugandan community to get rid of the dictatorial regimes of the day. President Museveni does accept resorting to use of witchcraft during his military bush days in an attempt to save his liberation struggle against the then dictatorial regimes of Uganda (Nakitende 2015). This not only points to legitimization of political power by means of witchcraft but also demonstrates the legitimate application of witchcraft in intra-elite competition for economic or political power (Kohnert 1996). Manipulation of supernatural powers by government officials is prevalent in several African countries (Diwan 2004). 
Application of witchcraft among co-wives in Busoga society is common and expected. This is in attempts to win back the husband's love away from the co-wife but also dealing with the co-wife directly; to scare them, and cause harm upon them including causing their death. In these circumstances rather than condemning the wife who practices witchcraft for love, women are warned against having love affairs with married men to avoid the dire consequences of witchcraft from the official wife. One interviewee stated as follows,

Young women are often blamed for the sufferings they go through if it is suspected to be coming from the official wife because they are blamed for breaching the peace of the official wife. Married women rally behind fellow elderly wives in condemnation of the young wife who interfered with the marriage. Any likelihood of suffering including death of the young wife due to suspected witchcraft will be blamed upon the victim for the interference she may have caused (D. Isabirye, personal interview, October 11, 2018).

Views expressed by the above interviewee communicate the gender relations that are reflected in witchcraft practices among the Basoga. They further communicate a high likelihood of witchcraft between women and subsequent approval of acts of witchcraft against fellow women, who are looked at as sources of marital complications. Women are expected to enjoy their domestic space without antagonism and anyone who does so, especially from a fellow woman, is treated without mercy. Cowives are also intimate strangers who must compete with one another for marital resources. This situation is a majorsource of conflict manifested in accusations of witchcraft and even violence between co-wives. When a woman leaves her husband's home, her children are left vulnerable to attack by their father's other wives (Lyons 1998). To avoid such unfortunate occurrences, married women are sympathised with when they undertake witchcraft to protect their marriages against potential co-wives.

Communal aspects of witchcraft are also common in communal sports activities. Specific communities have their community witches who are consulted when they have challenges against each other. Two examples stand out during sports competitions and warfare. A community Witch can make warriors of another community become blind right at the battle front. They may experience dizziness, or even turn against themselves and kill each other instead of attacking the enemy forces. Using familiars, a witch of a community can blind sports team of another community making them incapable of competing in a sport. He can send poisonous substances that make their bodies weak or even have their strongest athlete to die on the eve of the competition. Whereas harm will have been caused upon members of another community, the witch will be praised by members of his/her community for enabling them to withstand their enemy forces either in sporting activities or warfare. Indeed, as Cohan (2011) has discussed, witchcraft is used as a means of gaining advantages, often at the expense of others. This is common in various ways to ensure success in warfare or in sports, to thwart a romantic rival, to win a political race, and to exact vengeance against an enemy interalia.

\section{CONCLuSion}

Witchcraft exist in all societies, although its conception differs from one society to another. Whereas witchcraft is associated with evil and destruction, it also promotes social peace and harmony through its 'levelling effect' on social status, living conditions and wealth. Where all are equally well or badly off and where social status is determined by acknowledged, time-honoured practice rather than by ambitious striving, the room for jealousy and quarrel is limited. Levelling, however, discourages individualism, individual initiative, enterprise and responsibility. That, in turn, encourages resort to witchcraft in order to increase one's material wellbeing. More particularly, individual initiative and the striving for excellence and success are strongly deterred by fear of the possibly gruesome consequences if outstanding performance leads to accusations of practicing witchcraft. Such practices are commonly viewed as being at the expense of other people. A society based on these attitudes naturally discourages economic change and progress. Whereas witchcraft ignites fear among many societies, there are exceptions that illustrate that the practice as an agency through which society regulates itself. Contrary to popular beliefs about general condemnation of witchcraft practices, there are acceptable communal witchcraft practices. Witchcrafthas a variety of social functions in African societies, the most important of which, undoubtedly, is as a response to social needs. Indeed, witchcraft beliefs remain central in the functional outlook of societies because they form part and parcel of the morals and sanctions for social control as well as regulatory mechanism for conflicts and social change and other witchcraft apologists, real witchcraft is a field of adventure and exploration 
into realms of fantasy offering a secret knowledge that some use to their own advantage. Witchcraft could for certain be said to be a theory of power and authority. Witchcraft is used to enhance power, authority, and social standing of those who practise it. Witchcraft is used as a fortification against harm from perceived enemies. Witchcraft will for a long time continue to be experienced, particularly as more and more people face the attendant socio-economic and political challenges associated with the modern world.

\section{REFERENCES}

[1] Ashforth, Adam. 2005. "Muthi, Medicine and Witchcraft: Regulating African Science in Post-Apartheid South Africa?" Social Dynamics, 31(2):211-242. DOI:10.1080/02533950508628714.

[2] Bauer, Bruce, L. 2017. "Cultural Foundations for Fear of Witchcraft in Africa." Journal of Adventist Mission Studies 13(1), 2.

[3] Ciekawy, Diane. 1998. "Witchcraft in Statecraft: Five Technologies of Power in Colonial and Postcolonial Coastal Kenya." African Studies Review 41(3):119-141.

[4] Cohan, John, A. 2011. "The Problem of Witchcraft Violence in Africa." Suffolk University Law Review 44(4):803-872.

[5] Cook, Albert, R. 1946. "Medical Fees Charged to Africans." C.570. Entebbe: Uganda National Archives.

[6] Cultural Research Center. 2003. Witchcraft, Divination and Healing among the Basoga. Kisubi: Marianum Publishing Company Ltd.

[7] Daily Monitor Editorial. 2016. "Stop glorifying witchcraft.” Daily Monitor, January 12.

[8] Diwan, Mohammed, A. 2004. "Conflict between State Legal Norms and Norms Underlying Popular Beliefs: Witchcraft in Africa as Case Study." Duke Journal of ComparativeandInternational Law 14(2): 351-388.

[9] Evans-Pritchard, Edward. 1937. Witchcraft, Oracles and Magic among the Azande. Oxford: Clarendon Press.

[10] Fields, Karen, E. 1982. "Political Contingencies of Witchcraft in Colonial Central Africa: Culture and the State in Marxist Theory." Canadian Journal of African Studies / Revue CanadienneDes Études Africaines 16(3): 567-593. Doi: 10.2307/484560.

[11] Gechiko-Nyabwari, Bernard. G. and Nkonge-Kagema, Dickson. 2014. "The Impact of Magic and Witchcraft in the Social, Economic, Political and Spiritual Life of African Communities." International Journal of Humanities, Social Sciences and Education (IJHSSE) 1(5): 9-18.

[12] Gershman, Boris. 2016. Witchcraft beliefs and the erosion of social capital: Evidence from Sub-Saharan Africa and beyond. Journal of Development Economics, 2016; 120: 182 DOI: 10.1016/j.jdeveco.2015.11.005

[13] Geschiere, Peter. 1998. "Globalization and the Power of Indeterminate Meaning: Witchcraft and Spirit Cults in Africa and East Asia." Development and Change 29: 811-837. doi:10.1111/1467-7660.00100.

[14] Geschiere, Peter. 2010. "Witchcraft and modernity: perspectives from Africa and beyond." In Sorcery in the black Atlantic, edited by Nicolau P. L, and Sansi, R., 233-258. Chicago: University of Chicago Press. http://www.jstor.org/stable/4091566.

[15] Hutton, Ronald. 2004. "Anthropological and Historical Approaches to Witchcraft: Potential for a New Collaboration?" The Historical Journal 47(2): 413-434.

[16] Isiko, Alexander. P\& Maate, Y. 2019. The Socio-cultural Perspectives of the Bakonzo of Uganda about Death. IOSR Journal of Humanities and Social Science 24 (4), 57-68

[17] Isiko, Alexander. P. 2019a. The Nexus between Traditional Healing and Societal Organisation: Reflections on Busoga Society Socio-Cultural, Economic and Political Organisation. Journal of Arts and Humanities, 8(8), 71-88.

[18] Isiko, Alexander. P. 2019b. State regulation of religion in Uganda: Fears and dilemmas of born-again churches. Journal of African Studies and Development, 11(6), 99-117

[19] Isiko, Alexander. P. 2018. Gender roles in traditional healing practices in Busoga (Doctoral dissertation). Leiden: Leiden University.

[20] Kantha, Sachi, S. 2014. "Medical Maladies during the Honeymoon: A review." International Medical Journal 21(3): 335-337.

[21] Kapferer, Bruce. 2002. "Outside all reason: Magic, Sorcery and epistemology in Anthropology." Social Analysis 46(3): 1-30.

[22] Kingsley, Mary, H. 1901. West African Studies. London: MacMillan.

[23] Kohnert, Dirk. 1996. "Magic and Witchcraft: Implications for Democratization and Poverty-Alleviating Aid in Africa." World Development: The Multi-Disciplinary Journal Devoted to the Study and Promotion of World Development 24(8): 1347-1355. https://doi.org/10.1016/0305-750x(96)00045-9. 
[24] Leistner, Erich. 2014. Witchcraft and African development. African Security Review, 23(1), 53-77, DOI: 10.1080/10246029.2013.875048

[25] Lyons, Diane. 1998. Witchcraft, Gender, Power and Intimate Relations in Mura Compounds in Dela, Northern Cameroon. World Archaeology,29(3), 344-362. Retrieved from www.jstor.org/stable/125035

[26] Magoola, Robert. 2013. "Engaging Witchcraft Accusations among Christians as a Vehicle of African Traditional Religious Self-Advocacy in African Contexts. The Asbury Journal68(1): 10.

[27] Meel, Banwari. 2009. "Witchcraft in Transkei Region of South African: case report." African Health Sciences 9(1): 61-64.

[28] Mesaki, Simeon. 1995. "The Evolution and Essence of Witchcraft in Pre-Colonial African Societies." Transafrican Journal of History 24: 162-177.http://www.jstor.org/stable/24328661

[29] Mufuzi, Friday. 2014 "The Practice of Witchcraft and the Changing Patterns of its Paraphernalia in the Light of Technologically Produced Goods as Presented by Livingstone Museum, 1930s-1973." Zambia Social Science Journal 5(1):5. http://scholarship.law.cornell.edu/zssj/vol5/iss1/5.

[30] Nakitende, Hadijah. 2015. A Thin Line Between Witchcraft and African Politics. The Sunrise November 7.

[31] Pels, Peter. 1998. "The Magic of Africa: Reflections on a Western Commonplace.” African Studies Review 41(3): 193-209. Doi: 10.2307/525359.

[32] Pels, Peter. 2003. "Introduction." In Magic and Modernity, edited by Birgit, M. and Pels, P., 1-38. Stanford, CA: Stanford University Press.

[33] Pels, Peter. 2014. The Futures of Witchcraft in Africa. Paper presented at a workshop at Leiden University, November 7. http://media.leidenuniv.nl/legacy/witchcraft-extenddescript-2).pdf.

[34] Russell, Jeffrey, B. and Lewis, Iona, M. 2016. "Witchcraft." Encyclopedia Britannica Inc. https://www. britannica.com/topic/witchcraft.

[35] Taylor, Kraupl, F. 1979. "Penis Captivus-did it occur?” Br Med J 2(6196): 977-978.

[36] Uganda Protectorate. 1957. "Ordinances and Subsidiary Legislations Containing Orders in Council, Rules, Regulations, Proclamations, Orders, Notices, Native Laws etc.” Entebbe. Uganda National Archives.

[37] World Bank. 2004 Traditional Medicine in Uganda: Historical Perspective, Challenges and Advances. Indigenous Knowledge(IK)Notes; no 67. Washington, DC: World Bank.

[38] Wyk, Ignatius, C. 2004. “African witchcraft in theological perspective.” HTS 60(4):1201-1228.

\section{AUTHOR BIOGRAPHY}

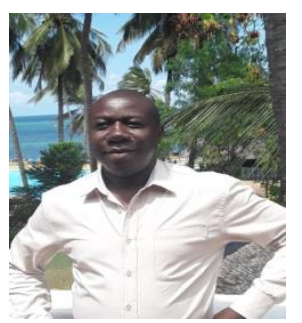

Isiko Alexander Paul is a Lecturer at Kyambogo University (Uganda) in the Faculty of Arts and Social Sciences, Department of Religious Studies \& Philosophy. He has diverse research interests, including Contemporary African Religious Experiences, Born Again Christian movements, Church History, and Gender and Religion. Isiko attained his $\mathrm{PhD}$ from Leiden University, Netherlands.

Citation:Isiko Alexander Paul. "An Expository Study of Witchcraft among the Basoga of Uganda". International Journal of Humanities Social Sciences and Education (IJHSSE), vol. 6, no.12, 2019, pp. 83-96. doi: http://dx.doi.org/10.20431/2349-0381.0612007.

Copyright:@ 2019 Authors. This is an open-access article distributed under the terms of the Creative Commons Attribution License, which permits unrestricted use, distribution, and reproduction in any medium, provided the original author and source are credited. 